\title{
Measuring Lifebuoy Ad Exposure in Building Awareness of KlikDokter Application Users during Pandemic COVID-19
}

\section{Mengukur Terpaan Iklan Lifebuoy dalam Meningkatkan Kesadaran Pengguna Aplikasi KlikDokter selama Pandemi COVID-19}

\author{
Halim Agung ${ }^{1}$, Rustono Farady Marta ${ }^{2}$, Vina Virshella ${ }^{3}$ \\ ${ }^{1,2,3}$ Universitas Bunda Mulia \\ 1,2,3 Jalan Lodan Raya No 2, North Jakarta, 14430, Jakarta, Indonesia \\ Email: ${ }^{1}$ hagung@ @undamulia.ac.id, ${ }^{2}$ rmarta@ bundamulia.ac.id, ${ }^{3}$ s35200022@ @student.ubm.ac.id
}

Received : July 18, 2021 ; Revised: August 10, 2021; Accepted: August 24,2021

\begin{abstract}
The COVID-19 pandemic is a disease outbreak that makes almost all humans unable to travel freely, especially in Indonesia. Lifebouy and KlikDokter as one of the health products that have strong relevance related to preventive measures for the spread of this virus in Indonesia are the focus of researchers. This study aims to analyze exposure to lifebouy advertisements in building brand awareness of KlikDokter application users during the current pandemic. Data analysis used IBM SPSS Statistics 26 and involved 107 samples using the positivism paradigm, quantitative approach, survey methods, and data collection instruments in the form of questionnaires. The results of this research shows that the significance value is less than 0.05 which indicates that optimizing advertising exposure on various digital channels is a top priority in an effort to encourage user awareness in the use of a health service application.
\end{abstract}

Keywords: advertising exposure; brand awareness; COVID-19; KlikDokter; Lifebuoy, survey.

Abstrak

Pandemi COVID-19 merupakan wabah penyakit yang membuat hampir seluruh manusia tidak dapat bebas berpergian terutama di Indonesia. Lifebouy dan KlikDokter sebagai salah satu produk kesehatan yang memiliki relevansi kuat terkait upaya preventif penyebaran virus di Indonesia menjadi fokus peneliti. Penelitian ini bertujuan untuk menganalisis terpaan Iklan Lifebouy dalam membangun kesadaran merek pengguna aplikasi KlikDokter di masa pandemi saat ini. Analisis data menggunakan IBM SPSS Statistics 26 dan melibatkan 107 sampel dengan menggunakan paradigma positivisme, pendekatan kuantitatif, metode survei, dan instrumen pengumpulan data berupa kuisioner. Hasil dari penelitian ini menunjukkan bahwa nilai signifikansi lebih kecil dari 0.05 yang menunjukkan bahwa optimalisasi terpaan iklan di berbagai saluran digital menjadi prioritas utama dalam upaya mendorong kesadaran pengguna dalam penggunaan suatu aplikasi layanan kesehatan.

Kata Kunci: COVID-19; terpaan iklan; kesadaran merek; KlikDokter; Lifebouy; survei. 


\section{Introduction}

Coronavirus (Menteri Kesehatan Republik Indonesia, 2020) is a large family of viruses that cause disease in humans and animals. In humans, it usually causes respiratory tract infections, ranging from the common cold to serious illnesses such as Middle East Respiratory Syndrome (MERS) and Severe Acute Respiratory Syndrome (SARS). A new type of coronavirus found in humans since an extraordinary event appeared in Wuhan, China, in December 2019, was later named Severe Acute Respiratory Syndrome Coronavirus 2 (SARS-COV2), and caused Coronavirus Disease-2019 (COVID-19).

The highest addition of daily cures came from DKI Jakarta with 1,282 cases and the cumulative number reached 70,392 cases. Common symptoms include fever $380 \mathrm{C}$, dry cough, and shortness of breath. If there are people who within 14 days prior to the appearance of these symptoms have traveled to an infected country, or have cared for/close contact with a person with COVID-19, then that person will be subjected to further laboratory tests to confirm the diagnosis.

Based on data from the Ministry of Health as of October 10, 2020 (Communication Team of the Committee for Corona Virus Disease 2019 (Covid-19) and National Economic Recovery, 2021), patients recovered from Covid-19 increased by 3,814 cases. With the cumulative number already breaking through 251,481 cases. This indicates that Indonesians still don't care about their own health, if they reflect on the habits of Indonesians in their daily activities, for example when they eat they don't wash their hands, when they come home from work they don't immediately clean themselves and so on.

The government also always reminds us to always follow the health protocols that are always informed through television media (Kurniawati et al., 2021). One of them (Lukman et al., 2020) is one of the Unilever companies, namely Lifebuoy which has participated in helping the government to remind the importance of maintaining health, especially in this case is to comply with health protocols.

Therefore, the focus of this research is how the effect of exposure to advertising builds awareness of a health product

\section{Theoretical Framework}

Communication (Cangara, 2000, 2016) is a process of exchanging information between two or more people which in the process will form understanding for each individual. Communication has several elements, namely the sender, the message, the sending media, the recipient and the influence of the message (Sasongko \& Marta, 2018). Communication is also divided into several categories, one of which is persuasive communication. Persuasive communication has several objectives, namely providing understanding to consumers, attracting consumers to buy certain products, introducing products so that they are easy to understand 
(Putri, 2016). The form of persuasive communication itself is advertising.

Advertising (Moriarty et al., 2011) a paid form of communication that uses various types of media (Marselina et al., 2019) namely mass media and interactive media to reach a broad audience in order to connect clear sponsors with buyers and provide information about products (goods, services, and ideas) which means that advertisements are not directed to people with certain categories (Christian, 2019), although these characteristics changed after the emergence of internal.

According to the Language Development and Learning Agency, advertising (Bahasa, 2016) is a message or news that aims to encourage, persuade the general public to be interested in the goods or services offered. Advertising also has the meaning of notification to the public about goods or services being sold, posted in mass media (such as newspapers and magazines) or in public places.

Advertising can also be interpreted as a form of non-personal communication about the organization (Ulfa \& Marta, 2017)(Wono \& Aji, 2020), products or services, and ideas. Advertising is a very important promotional strategy, especially for companies that want their goods or services to be known by the public (Tianotak \& Asy'ari, 2019). Many companies prefer advertising placed on mass media so that their goods or services are known to many people because advertising on mass media is considered efficient because of minimal costs and getting a large audience. (Kristianto \& Marta, 2019).

One way to do promotion is by exposure to advertising. Exposure (Munawwaroh \& Lubis, 2018) means that the condition of the community is exposed to a lot of messages that are disseminated on social media. Exposure can be interpreted as an activity of hearing, seeing, and reading messages in the media or having attention to these messages that can occur in individuals or groups (Amali, 2019). But the conditions will be different if faced with the current pandemic conditions. Therefore, this research will prove the effect of advertising exposure on brand awareness of health products.

Exposure to advertising impressions is mostly done on the internet, especially social media. Social media is a website application (Prasetyo, 2021) that can create communication that can make people interact in groups. Social media has become part of the e-marketing strategy. Social media includes Facebook, Instagram, Twitter, Youtube, Blogs, and others.

Advertising exposure can be measured through three dimensions (Haliem et al., 2019), the first is frequency, which is routine or how often people use the media and understand the message conveyed. The second is attention, which is an interest in someone in using the media and consuming the messages contained in the media. The third is duration, which is how long people use the media to understand and get messages from the media. The development of technology on Youtube's social media has made 
many companies exposed to advertising on Youtube (Febrida \& Oktavianti, 2020) which in turn raises the perception of consumers who are exposed to advertising exposure. Perception is the process by which a person selects, organizes, and interprets message inputs to create a picture of life (Saputra \& Semuel, 2013).

Perception is divided into three processes, namely selective attention, selective distortion and selective memory. Selective attention is someone who receives a lot of stimuli every day (flooded with advertisements), from that many stimuli someone will automatically filter the messages he gets. Selective distortion is someone directing information to fit our thinking. Selective memory is when a person will erase their memory of many things they have learned, but will think about or remember information that they believe in (Kotler \& Armstrong, 2018).

A brand (Kotler \& Armstrong, 2018) is a name, term, sign, symbol, design, or a combination of these intended to identify the products or services of one person or seller and to differentiate them from those of competitors. So the brand identifies the maker or seller of a product. The brands used in this study are Lifebouy and KlikDokter. Meanwhile, brand awareness is the ability and behavior of consumers (Agung et al., 2020) to recognize or remember that a brand is a member of a particular product category. Brand awareness is one of the strategies to achieve brand equity. Brand equity (Marta \& William, 2016) is a set of assets attached to a brand, namely names and symbols that are able to add or reduce the value of a product or service for the company or customer so that brand equity has an emotional form and network strength owned by a brand, where brand awareness itself is the ability of a prospective buyer to recognize and recall a brand. Furthermore, brand awareness is created and enhanced by increasing brand familiarity through repeated exposure so that consumers feel familiar with the brand (Shabbir et al., 2017).

Several ways that companies must do in order to achieve brand awareness, among others (Aaker, 1996) is that the message that the company wants to convey to its consumers must be easy to remember and different from other products. In addition, there must be a relationship between the brand and its product category. If the product has a symbol, the symbol used should be associated with the brand. Brand extension can be used so that the brand is increasingly remembered or known by consumers. Event Sponsorship and Publicity can be used to achieve brand awareness. Companies must continue to repeat the messages conveyed, this is done because forming consumer memories of a brand is more difficult than introducing a brand to consumers (Putra, 2021).

There are four levels of brand awareness. Unaware of brand (not aware of the brand) where this category includes brands that remain unknown even though assisted recall has been carried out. Brand Recognition where this category includes product brands that are 
known to consumers after being reminded through assisted recall. Brand recall, where this category includes brands in the category of a product that consumers remember without having to recall, is termed unassisted recall. Top of Mind where this category includes product brands that first appear in the minds of consumers in general.

There are four indicators that can be used to determine how far consumers are aware of a brand. Recall, which is how far consumers can remember when asked what brands are remembered. Recognition, which is how far consumers can recognize the brand belongs to a certain category. Purchase, which is how far consumers will enter a brand into alternative choices when buying a product or service. Consumption, which is how far consumers can recognize the brand when using a product or service. The higher the level of brand awareness, the more purchases that are owned by consumers to recognize a particular product to influence purchasing decisions (Cahyani \& Sutrasmawati, 2016).

In research conducted by Gunawan, the brand awareness factor does not influence customers to repurchase the products they buy but creates optimal customer satisfaction, service excellence, massive promotion and advertising, guarantees of security and ease of use of applications, and ease of shopping, especially for the ecommerce industry is the most important factor in determining consumer loyalty and intention to repurchase a product (Ilyas et al., 2020).
Likewise with research conducted by Pantea, the brand awareness factor (Foroudi, 2019) of the name and logo of a hotel does not affect consumer awareness of the existence of a hotel that he knows but the reputation of a hotel which is a strong factor for a consumer.

This research will look for the impact of exposure to advertising carried out by a health product. How strong is the exposure of the advertisement to the brand awareness of a health product.

\section{Research Methods}

In analyzing the results of hypothesis testing in this study where the hypothesis used in this study is how the effect of advertising exposure on health product brand awareness, researchers rely on the positivistic paradigm to relate the effect of Lifebouy advertising exposure to consumer brand awareness. This study relies on the use of quantitative research approaches (Lo et al., 2020) (Strijker et al., 2020) with the classical assumption test using IBM SPSS Statistics 26 software.

This research is a quantitative study using a questionnaire as a research instrument. Data collection in this study was carried out using data analysis (Misbahuddin \& Hasan, 2013) (Memon et al., 2020). This analysis allows a minimum number of samples to be used in this study and requires information relating to power, effect size and significance level to calculate the minimum sample size. The power value contained in it is the ability of statistical calculations to correctly reject the null hypothesis even though it is wrong which in this 
study the power value is 0.95 . On the other hand, the effect size measures the actual influence of each independent variable on the dependent variable which in this study the effect size value is 0.15 . Furthermore, the level of significance relates to the probability of rejecting the null hypothesis which in this study is worth 0.05 .

Researchers use the $\mathrm{G}^{*}$ Power application as an application that implements power analysis in its application. based on the calculation of the $\mathrm{G}^{*}$ Power application, 107 was obtained as the minimum sample size used in this study. The sample in this study was taken randomly from online application users who made multi-product purchases in recent years because population distribution is so wide, it is difficult to define the number. The population of this research is all online application users in Indonesia, both in Java and outside Java.
4. Research Results and Discussion Based on the results of the research test, it was found that there were 74 male respondents and 33 female respondents. This explains that in this study the majority came from the male gender.

This shows that the initiative to run a number of business successions is carried out by more men than women. The range of age distribution of respondents in this study was the majority in the age of 17-25 years, as many as 84 people.

\section{Measuring Validity of Variables}

Before testing the hypothesis, all items in each question on the questionnaire in this study will be tested for validity. Table 1 is a summary table of the results of the validity test of the advertising exposure variable represented by the TI code and the brand awareness variable represented by the BA code.

Table 1. Two Variable Validity Test Results

\begin{tabular}{|c|c|c|c|c|c|c|}
\hline $\begin{array}{c}\text { INDICAT } \\
\text { OR }\end{array}$ & $\begin{array}{c}\text { RCOU } \\
\text { NT }\end{array}$ & $\begin{array}{c}\text { INDICAT } \\
\text { OR }\end{array}$ & $\begin{array}{c}\text { RCOU } \\
\text { NT }\end{array}$ & $\begin{array}{c}\text { INDICAT } \\
\text { OR }\end{array}$ & $\begin{array}{c}\text { RCOU } \\
\text { NT }\end{array}$ & $\begin{array}{c}\text { RTABL } \\
\text { E }\end{array}$ \\
\hline AE11 & 0.688 & BA11 & 0.669 & BA61 & 0.851 & 0.1882 \\
\hline AE12 & 0.665 & BA12 & 0.721 & BA62 & 0.843 & 0.1882 \\
\hline AE13 & 0.623 & BA21 & 0.731 & BA63 & 0.843 & 0.1882 \\
\hline AE14 & 0.672 & BA22 & 0.740 & BA64 & 0.854 & 0.1882 \\
\hline AE21 & 0.758 & BA31 & 0.715 & BA71 & 0.801 & 0.1882 \\
\hline AE22 & 0.733 & BA32 & 0.719 & BA72 & 0.744 & 0.1882 \\
\hline AE23 & 0.699 & BA33 & 0.693 & BA81 & 0.820 & 0.1882 \\
\hline AE24 & 0.739 & BA34 & 0.748 & BA82 & 0.831 & 0.1882 \\
\hline AE31 & 0.694 & BA41 & 0.855 & BA91 & 0.849 & 0.1882 \\
\hline AE32 & 0.697 & BA42 & 0.839 & BA92 & 0.813 & 0.1882 \\
\hline AE33 & 0.784 & BA43 & 0.766 & BA101 & 0.832 & 0.1882 \\
\hline AE34 & 0.749 & BA44 & 0.754 & BA102 & 0.814 & 0.1882 \\
\hline & & BA51 & 0.841 & BA103 & 0.863 & 0.1882 \\
\cline { 3 - 7 } & & BA52 & 0.819 & BA104 & 0.869 & 0.1882 \\
\cline { 3 - 7 } & BA53 & 0.797 & & & 0.1882 \\
\hline
\end{tabular}


In order to test the reliability in this study, it was tested using a
Croncbach's alpha value above 0.6 which can be seen in table 2 .

Table 2. Ad Exposure Reliability Testing and Brand Awareness

\begin{tabular}{|c|c|c|c|}
\hline \multicolumn{2}{|c|}{ Ad Exposure (AE) } & \multicolumn{2}{c|}{$\begin{array}{c}\text { Brand Awareness } \\
\text { (BA) }\end{array}$} \\
\hline $\begin{array}{c}\text { Cronbach's } \\
\text { Alpha }\end{array}$ & $\begin{array}{c}\text { N of } \\
\text { Items }\end{array}$ & $\begin{array}{c}\text { Cronbach's } \\
\text { Alpha }\end{array}$ & $\begin{array}{c}\text { N of } \\
\text { Items }\end{array}$ \\
\hline 0.910 & 12 & 0.980 & 30 \\
\hline
\end{tabular}

Source: processed by researchers

The advertising exposure variable can be seen in table 2, it can be seen that the Cronbach's alpha value is 0.910 which can be concluded that all statement items from the questionnaire to measure the advertising exposure variable are declared to have good reliability. The brand awareness variable can also be seen in table 2, it can be seen that the value of Cronbach's alpha is 0.980 which can also be concluded that all statement items to measure the brand awareness variable are declared to have good reliability.

\section{Testing Data Distribution}

In order to determine the type of data distribution, the researchers involved a series of classical assumption tests carried out with three tests, namely normality, multicollinearity and heteroscedasticity tests (Charpentier et al., 2019). The normality test in this research was carried out using the Kolmogorov-Smirnov test. The normality test was tested with advertising exposure as the independent variable and brand awareness as the dependent variable.

Based on the Normality Test using the Kolmogorov-Smirnov which can be seen in Table 3, it can be seen that the value of the normality test results based on the primary data obtained by the researcher is Asymp. Sig. (2-tailed) $0.200>0.05$. This means that the results of the normality test are normally distributed.

Table 3. Test Results for Normality of Advertising Exposure and Brand Awareness

\begin{tabular}{|c|c|c|c|c|c|c|c|}
\hline \multirow{3}{*}{$\mathrm{N}$} & \multicolumn{2}{|c|}{ Normal Parameters } & \multicolumn{2}{c|}{ Most Extreme Differences } & Test & Asymp \\
\cline { 2 - 5 } & Mean & Std. & Absolut & Positiv & Negativ & Statisti & . Sig. \\
& & Deviation & $\mathrm{e}$ & $\mathrm{e}$ & $\mathrm{e}$ & $\mathrm{c}$ & $(2-$ \\
\hline
\end{tabular}




\begin{tabular}{|c|c|c|c|c|c|c|c|}
\hline & & & & & & & tailed) \\
\hline 10 & 0.000000 & 15.7713745 & 0.050 & 0.050 & -0.043 & 0.050 & $\begin{array}{c}0.200^{\mathrm{c},} \\
\mathrm{d}\end{array}$ \\
\hline
\end{tabular}

Source: processed by researchers

The multicollinearity test (Charpentier et al., 2019) aims to test whether in the regression model there is a correlation between independent variables. This test is carried out using VIF with criteria, if the VIF of an independent variable is $<10$, it can be concluded that the independent variable does not occur multicollinearity. This test is also carried out using Tolerance with criteria, if the Tolerance of an independent variable is $>0.1$, it can be concluded that the independent variable is not multicollinear.

Based on Table 4, the results of the classical assumption test show that there is no independent variable that has a VIF value of more than 10 . Thus, it can be concluded that there is no symptom of multicollinearity between independent variables in the regression model.

Table 4. Ad Exposure Multicollinearity Test Results

\begin{tabular}{|c|c|c|}
\hline \multirow{2}{*}{ Variable } & \multicolumn{2}{|c|}{ Collinearity Statistics } \\
\cline { 2 - 3 } & Tolerance & VIF \\
\hline Ad Exposure $(\mathrm{X})$ & 0.933 & 1.072 \\
\hline
\end{tabular}

Source: processed by researchers

Heteroscedasticity test (Charpentier et al., 2019) in this study was conducted to determine whether or not there is a variance inequality from one observation residual to another in the Spearman Rank regression model. This test uses a significance value (Sig.) which must be greater than 0.05 so that heteroscedasticity does not occur in the regression model. If seen from Table 5, the significance value (Sig.) for the advertising exposure variable is $0.820>0.05$. It can be concluded that there is no symptom of heteroscedasticity in the regression model, so the data obtained can be continued in hypothesis testing.

Table 5. Ad Exposure Heteroscedasticity Test Results

\begin{tabular}{|c|c|}
\hline Variable & Sig. (2-tailed) \\
\hline $\begin{array}{c}\text { Ad Exposure } \\
(\mathrm{X})\end{array}$ & 0.820 \\
\hline
\end{tabular}

Source: processed by researchers

\section{Confirmation of Initial Alleged Research}

Hypothesis testing was carried out using a partial test (T-Test). T test was conducted to show how far the influence of one independent variable. Individually in explaining the variation of the dependent variable (Ghozali, 2016). The basis for making the decision is if the significance is $<0.05$ then $\mathrm{H} 0$ is rejected and $\mathrm{H} 1$ is accepted, which 
means that there is an influence of dependent variable.

the independent variable on the

Table 6. Partial Testing Results (T-Test)

\begin{tabular}{|c|c|c|c|}
\hline Model & Variable & $\mathrm{T}$ & Sig. \\
\hline \multirow{2}{*}{1} & (Constant) & -0.732 & 0.466 \\
\cline { 2 - 4 } & Ad Exposure (X) & 9.568 & 0.000 \\
\hline
\end{tabular}

Source: processed by researchers

$\mathrm{H1}$ : there is an influence of $\mathrm{AE}$ on BA

$\mathrm{H} 2$ : there is no influence of $\mathrm{AE}$ on BA

The AE variable in Table 5 shows a significance value of 0.000 , the value is less than 0.05 , so the results are said to be significant. Thus, there is an influence between the $\mathrm{AE}$ variable and the BA variable. From the results given by Table 5 , it shows that the Advertising Exposure as abreviated as AE's factor used by companies to promote a product has a very meaningful impact on brand awareness for customers of a product so that consumers will pay special attention to the advertised product. (Cahyani \& Sutrasmawati, 2016).

\section{Conclusions and Suggestions}

Lifebouy \& KlikDokter acts as a provider of various health products, both health products and services that are presented to the people of Indonesia by relying on a number of stimuli. This research succeeded in identifying the impression of exposure to Lifebouy advertising which in this case is represented in Ad Exposure (AE).

In turn, this research hypothesis shows a significant effect on KlikDokter's Brand Awareness (BA). It is hoped that the results of this study can provide a reference for various stakeholders, especially regarding the implementation of marketing communications through digital business channels, which in this case are discussed in the form of Brand Lifebouy. The aggressiveness of exposure to advertising is one of the factors in formulating an onlinebased marketing communication strategy.

\section{References}

Aaker, D. A. (1996). Measuring Brand Equity Across Products and Markets. California Management Review. https://doi.org/10.2307/4116584 5

Agung, H., Christian, M., \& Loisa, J. (2020). Perilaku Pengguna Shopee Terhadap Pembelian Multiproduk dengan Pendekatan Theory of Reasoned Action. Go-Integratif: Jurnal Teknik Sistem Dan Industri. https://doi.org/10.35261/gijtsi.v 1i01.4005

Amali, M. T. (2019). Pengaruh Terpaan Iklan Online Dan Kelompok Referensi Terhadap Perilaku Adopsi Go-Jek Di Kota Semarang Yang Dimediasi Oleh Sikap Konsumen. Jurnal Audience, 2(1), 1-19. 
https://doi.org/10.33633/ja.v2i1. 2692

Bahasa, B. P. dan P. (2016). Iklan. Kbbi.Kemdikbud.Go.Id. https://kbbi.kemdikbud.go.id/en tri/iklan

Cahyani, K. indra, \& Sutrasmawati, E. (2016). Pengaruh Brand Awareness dan Brand Image terhadap Keputusan Pembelian. Management Analysis Journal, 5(4).

https://journal.unnes.ac.id/sju/in dex.php/maj/article/view/8350/7 734

Cangara, H. (2000). Pengantar Ilmu Komunikasi

(Cetakan

Keempat). In Jakarta: PT Rajagrafindo Persada.

Cangara, H. (2016). Pengantar Ilmu Komunikasi (Edisi Kedua). In Jakarta: $\quad P T \quad$ Rajagrafindo Persada.

Charpentier, A., Ka, N., Mussard, S., \& Ndiaye, O. H. (2019). Gini regressions and heteroskedasticity.

Econometrics.

https://doi.org/10.3390/econom etrics7010004

Christian, M. (2019). Telaah Keniscayaan Iklan Di Kanal Youtube Sebagai Perilaku Khalayak Di Kalangan Milenial. Bricolage: Jurnal Magister Ilmu Komunikasi, 5(02), 141. https://doi.org/10.30813/bricola ge.v5i02.1890

Communication Team of the Committee for Corona Virus Disease 2019 (Covid-19) and National Economic Recovery. (2021). The Covid-19 National
Task Force Informs the World Community about Pandemic Mitigation. Covid19.Go.Id. https://covid19.go.id/berita/covi d-19-national-task-forceinforms-world-communityabout-pandemic-mitigation

Febrida, R., \& Oktavianti, R. (2020). Pengaruh Terpaan Iklan di Media Sosial Youtube terhadap Persepsi Konsumen (Studi terhadap Pelanggan Iklan Tiket.com di Youtube). Prologia, 4(1). https://doi.org/10.24912/pr.v4i1 .6471

Foroudi, P. (2019). Influence of brand signature, brand awareness, brand attitude, brand reputation on hotel industry's brand performance. International Journal of Hospitality Management, 76, 271-285.

https://doi.org/10.1016/J.IJHM. 2018.05.016

Ghozali, I. (2016). Aplikasi Analisis Multivariate dengan Program IBM SPSS 23. (Edisi 8). Semarang: Badan Penerbit Universitas Diponegoro.

Haliem, P. O., Rusdi, F., \& Utami, B. (2019). Pengaruh Terpaan Media Line Webtoon Wonderwall terhadap Opini Pembaca Mengenai Isu Kesehatan Mental. Prologia, 2(2).

https://doi.org/10.24912/pr.v2i2 .3730

Ilyas, G. B., Rahmi, S., Tamsah, H., Munir, A. R., \& Putra, A. H. P. K. (2020). Reflective model of brand awareness on repurchase 
intention and customer satisfaction. Journal of Asian Finance, Economics and Business, 7(9), 427-438. https://doi.org/10.13106/JAFEB .2020.VOL7.NO9.427

Kotler, P., \& Armstrong, G. (2018). Kotler \&amp; Armstrong, Principles of Marketing | Pearson. In Pearson.

Kristianto, B. R. D., \& Marta, R. F. (2019). Simplifikasi Ritual Harai Dan Dimensi Kultural Hofstede Dalam Iklan Forte Versi Sumo. Bricolage: Jurnal Magister Ilmu Komunikasi, 5(01), 091. https://doi.org/10.30813/bricola ge.v5i01.1744

Kurniawati, L. S. M. W., Marta, R. F., \& Amanda, M. (2021). Utilization of COVID-19 Digital Media Literacy Through The New Habit Marble Online Game in Early Children. Journal Communication Spectrum, $10(2)$. https://doi.org/10.36782/jcs.v10 i2.2142

Lo, F. Y., Rey-Martí, A., \& BotellaCarrubi, D. (2020). Research methods in business: Quantitative and qualitative comparative analysis. In Journal of Business Research. https://doi.org/10.1016/j.jbusres .2020 .05 .003

Lukman, S. L. N., Marta, R. F., \& Wahjudi, S. (2020). Publicity of Sido Muncul Corporate Social Responsibility News Content During Covid-19 Pandemic. The Journal of Society and Media, 4(2), 406. https://doi.org/10.26740/jsm.v4 n2.p406-424

Marselina, M., Sadono, T. P., \& Marta, R. F. (2019). Konstruksi Kekeluargaan, Idealisme Pekerja PERS, dan Rasa Memiliki pada Jurnalis FEMINA GROUP. Jurnal Audience, 2(1). https://doi.org/10.33633/ja.v2i1. 2693

Marta, R. F., \& William, D. M. (2016). Studi Terpaan Media Pemasaran Melalui Posting Instagram Terhadap Ekuitas Merek Pelanggan Sumoboo! (Analisis Eksplanatif pada Komunitas Food Blogger \#WTFoodies). Jurnal Komunikasi.

https://doi.org/10.24912/jk.v8i1. 50

Memon, M. A., Ting, H., Cheah, J.H., Thurasamy, R., Chuah, F., \& Cham, T. H. (2020). Sample Size for Survey Research: Review and Recommendations. Journal of Applied Structural Equation Modeling, 4(2). https://doi.org/10.47263/jasem.4 (2) 01

Menteri Kesehatan Republik Indonesia. (2020). Keputusan Menteri Kesehatan Republik Indonesia Nomor HK.01.07/MenKes/413/2020 Tentang Pedoman Pencegahan dan Pengendalian Corona Virus Disease 2019 (Covid-19). MenKes/413/2020, 2019.

Misbahuddin, \& Hasan, I. (2013). Analisis Data Penelitian Dengan Statistik (2nd ed.). Bumi Aksara. 
Moriarty, S., Mitchell, N., \& Wells, W. (2011). Advertising (8th Editio). Penerbit Kencana.

Munawwaroh, P. R., \& Lubis, E. E. (2018). Pengaruh Terpaan Media pada Akun Instagram @exploresiak terhadap Minat Kunjungan Wisata ke Siak Sri Indrapura. Jom Fisip, 5(1). https://jom.unri.ac.id/index.php/ JOMFSIP/article/view/16646

Prasetyo, E. (2021). Pengaruh Functional Quality dan Hedonic Quality Terhadap Loyalty Pada Flashpacker OTA AGODA. Digismantech (Jurnal Program Studi Bisnis Digital), 1(1), 3345.

https://doi.org/10.30813/digism antech.v1i1.2290

Putra, I. G. W. S. (2021). Evaluasi Pengaruh Product Quality, Product Innovation dan Marketing Promotion Terhadap Brand Image IKEA. Digismantech (Jurnal Program Studi Bisnis Digital), 1(1), 110. https://doi.org/10.30813/digism antech.vli1

Putri, P. K. (2016). Aplikasi Pendekatan-Pendekatan

Persuasif Pada Riset Komunikasi Pemasaran: Iklan Melibatkan Penciptaan dan Penerimaan Pesan Komunikasi Persuasif Mengubah Perilaku Pembelian. Jurnal The Messenger, $8(1)$. https://doi.org/10.26623/themes senger.v8i1.313

Saputra, R., \& Semuel, H. (2013). Analisa Pengaruh Motivasi, Persepsi, Sikap Konsumen
Terhadap Keputusan Pembelian Mobil Daihatsu Xenia di Sidoarjo. Jurnal Manajemen Pemasaran, 1(1). http://publication.petra.ac.id/ind ex.php/manajemenpemasaran/article/view/69

Sasongko, Y. P. D., \& Marta, R. F. (2018). Ekspresi Identitas Melalui Relasi Ayah dan Anak Pada Iklan Youtube Grab Official. Bricolage: Jurnal Magister Ilmu Komunikasi. https://doi.org/10.30813/bricola ge.v4i02.1656

Shabbir, M. Q., Khan, A. A., \& Khan, S. R. (2017). Brand Loyalty Brand Image and Brand Equity: the Mediating Role of Brand Awareness. International Journal of Innovation and Applied Studies. http://www.ijias.issrjournals.org/abstract.php?article =IJIAS-16-237-03

Strijker, D., Bosworth, G., \& Bouter, G. (2020). Research methods in rural studies: Qualitative, quantitative and mixed methods. Journal of Rural Studies. https://doi.org/10.1016/j.jrurstu d.2020.06.007

Tianotak, J., \& Asy'ari, N. A. S. (2019). Makna Tagline 'Menjadi Yang Terbaik' Iklan Telkomsel Versi Pilot Papua Riko Kabak. Bricolage : Jurnal Magister Ilmu Komunikasi, 5(01), 049. https://doi.org/10.30813/bricola ge.v5i01.1742

Ulfa, R., \& Marta, R. F. (2017). Implementasi Komunikasi 
Pemasaran Terpadu Pada

Yayasan Nurul Ibad Jakarta

Timur. Bricolage: Jurnal

Magister Ilmu Komunikasi, 2(02), 1-11. https://doi.org/10.30813/bricola ge.v2i02.835

Wono, H. Y., \& Aji, I. D. K. (2020).
Preferensi Komunikasi

Pemasaran Terpadu Perguruan Tinggi Di Surabaya Pada Era Posmoderen. Bricolage: Jurnal Magister Ilmu Komunikasi, 6(02), 171. https://doi.org/10.30813/bricola ge.v6i02.2146 